\title{
The Hidden Human and Environmental Costs of Regulatory Delay
}

By Catherine O'Neill, Amy Sinden, Rena Steinzor, James Goodwin, and Ling-Yee Huang 


\section{CENTER FOR \\ PROGRESSIVE REFORM \\ WHITE PAPER \#907}

\section{October 2009}

\section{Acknowledgments}

The Center for

Progressive Reform is grateful to the Public

Welfare Foundation for

its generous support of this project.

Printed in the U.S.A.

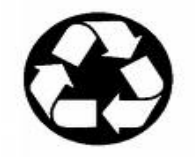

\section{About the Center for Progressive Reform}

Founded in 2002, the Center for Progressive Reform is a 501(c)(3) nonprofit research and educational organization comprising a network of scholars across the nation dedicated to protecting health, safety, and the environment through analysis and commentary. CPR believes sensible safeguards in these areas serve important shared values, including doing the best we can to prevent harm to people and the environment, distributing environmental harms and benefits fairly, and protecting the earth for future generations. CPR rejects the view that the economic efficiency of private markets should be the only value used to guide government action. Rather, CPR supports thoughtful government action and reform to advance the well-being of human life and the environment. Additionally, CPR believes people play a crucial role in ensuring both private and public sector decisions that result in improved protection of consumers, public health and safety, and the environment. Accordingly, CPR supports ready public access to the courts, enhanced public participation and improved public access to information. The Center for Progressive Reform is grateful to the Public Welfare Foundation for funding this report, as well as to the Bauman Foundation, the Deer Creek Foundation, and the Open Society Institute for their generous support of its work in general.

This report is a collaborative effort of the following member scholars and staff of the Center for Progressive Reform: Catherine A. O’Neill, Seattle University School of Law; Amy Sinden, Temple University Beasley School of Law; Rena Steinzor, University of Maryland School of Law; James Goodwin, CPR Policy Analyst; and Ling-Yee Huang, CPR Policy Analyst

For more information about the authors, see page 21.

www.progressivereform.org

For media inquiries contact Matthew Freeman at mfreeman@progressivereform.org or Ben Somberg at bsomberg@progressivereform.org.

For general information, email info@progressivereform.org

(C) 2009 Center for Progressive Reform 


\section{Introduction}

Each year dozens of workers are killed, thousands of children harmed, and millions of dollars wasted because of unjustifiable delays in federal regulatory action. The costs of regulatory delay accrue every time the federal protector agencies - those created by Congress to protect health, safety, and the environment—fail to take timely action to prevent the kind of serious and pressing threats Congress intended for them to address. Thus, when the Occupational Safety and Health Administration (OSHA) vacillates over a new rule to regulate the use of cranes and derricks, the costs come in the form of construction workers killed or injured when their equipment collapses or is improperly used. Similarly, when the Environmental Protection Agency (EPA) issues a regulation that postpones reductions of mercury emissions from U.S. power plants, the inevitable cost is the tens of thousands of children born every year with elevated mercury in their blood, at levels high enough to leave them with irreversible brain damage.

Such delays in regulatory action have become commonplace, part of the wallpaper of Washington's regulatory process for the protector agencies- the Consumer Product Safety Commission (CPSC), EPA, the Food and Drug Administration (FDA), the National Highway Traffic Safety Administration (NHTSA), and OSHA. Outside a small circle of advocates, it has gone largely unnoticed that over the last 10 years OSHA has issued comprehensive workplace regulations for only two chemicals. This small regulatory output from OSHA is astounding, considering that literally hundreds of industrial chemicals in commerce today have either no regulatory standards at all or are sold and used under standards that have not been updated in 40 years, and thus do not reflect anything learned about the chemicals and their impact on human health during that time. Meanwhile at EPA, after years of deliberate delay, the agency is only now starting to make some progress on addressing the greatest environmental challenge of our time: global climate change.

For those who care to examine them, the human and economic costs of regulatory delay are sometimes easy to identify. A delay in regulating toxic pollution might cause death or disease in humans, damage to fragile ecosystems, or massive clean-up costs for future generations. Other human and economic costs may be less obvious, but are no less important. For example, unregulated power plant emissions of mercury will cause developmental delays for some American children. Not only will they and their families suffer as a result, but taxpayers will end up footing the bill for providing special education to children who suffer brain damage. Also less obvious are the social costs of regulatory delay. For example, each instance of delay feeds public disillusionment with the nation's democratic institutions, as voters conclude that they cannot rely on the federal government to prevent serious health, safety, and environmental threats.

Regardless of how the costs of regulatory delay are measured, they represent real harms to real people and the environment—harms that are by definition completely preventable. 


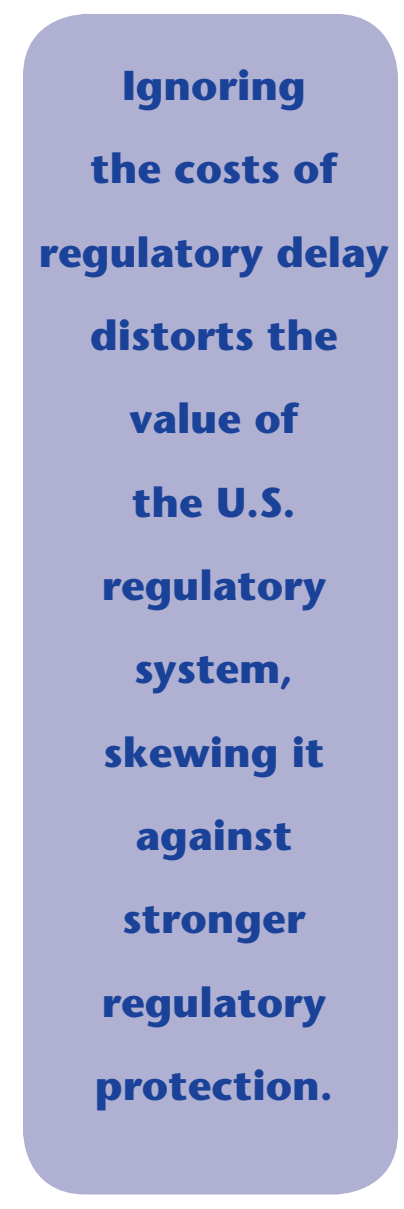

Moreover, these costs affect everyone from vulnerable subpopulations, such as children and the poor, to mighty industries, such as coal-fired power plants.

Despite its significance, the problem of regulatory delay and the costs it generates has been virtually ignored in the debate over the general wisdom of the U.S. regulatory system over the last 30-plus years. Opponents of the regulatory system have deliberately framed this debate in terms of the "costs and benefits" of regulatory action, implying that regulatory inaction caused by regulatory delay is somehow cost-free. The one-sided nature of this debate is perhaps best exemplified by the White House Office of Management and Budget's annual Report to Congress on the Benefits and Costs of Federal Regulations, as required by the 2001 Regulatory Right-to-Know Act. These annual reports document in painstaking detail the quantified and monetized costs and benefits of regulatory action, providing aggregate estimates of these costs and benefits for many of the regulations that federal agencies have issued over the previous year as well as over the previous ten years. Not once, however, have these reports ever sought to document the costs of regulatory delay.

The problem with ignoring the costs of regulatory delay is that it provides an incomplete picture of the value of the U.S. regulatory system-one that is inevitably skewed against stronger regulatory protection. Broadly speaking, the purpose of this white paper is to begin the process of filling in the rest of this picture, so that in the future the debate over the general wisdom of the U.S. regulatory system can continue on more robust and balanced terms. To this end, this white paper presents three case studies. Each tells the story of a recent or ongoing example of regulatory delay that has caused real harm to Americans and their environment:

- The first case study examines how EPA first delayed regulating power plant mercury emissions, despite detailed instructions in the 1990 Clean Air Act Amendments, and then actually attempted to adopt a regulatory program that was not only contrary to these detailed instructions but also intentionally postponed emissions reductions until after 2020. As a result of EPA's continuing failure to regulate these emissions, tens of thousands of American babies are born each year with unsafe levels of mercury in their blood-levels high enough to cause brain damage and other neurological problems. This regulatory delay also may contribute to hundreds of cases of preventable heart disease in adults every year and untold environmental harms.

- The second case study examines how EPA has for decades abdicated its clear duty under the Clean Water Act to control the spread of invasive species from ships' ballast water discharges. A federal court recently ordered EPA to begin regulating these discharges, but invasive species have already done considerable damage. For example, since it was first introduced in the 1980s, the zebra mussel—an invasive species carried to the United States in ships from Eastern Europe-has spread to hundreds of U.S. waterbodies, causing an estimated $\$ 1$ billion in damages every year, by clogging water intake pipes at power plants and other industrial facilities. Zebra 
mussel infestations have also permanently altered the fragile ecosystems of lakes and rivers across the country.

- The third case study examines how a much-needed new rule updating regulatory standards for the use of cranes, derricks, and other heavy machinery at construction sites has remained stalled at OSHA for the last five years. The existing standards are now 40 years old and are in dire need of updating to account for changes in technology and construction practices. OSHA's failure to issue the new rule has been costly: The agency estimates that it would save dozens of lives and prevent well over 100 injuries every year.

From these case studies, it is clear that costs of regulatory delay are diverse, extensive, and can be quite severe. These case studies also make it clear that regulatory delay is a systemic problem - not one that is peculiar to any one regulatory agency or to any one presidential administration—and thus will require a systematic solution to correct.

\section{CASE STUDY: Mercury Emissions from Power Plants}

The 1990 Clean Air Act instructed EPA to determine whether mercury emissions from coal-fired power plants posed a threat to public health by November 1994, and if it found such a threat, to adopt regulations controlling those emissions. Now, more than a decade and a half later, there is still no rule. Meanwhile, some 637,000 American babies are born each year with unsafe levels of mercury in their blood as a result of exposure to human-based sources. An estimated 10 percent of American women of childbearing age have similar, unsafe blood mercury levels. This number nearly triples for women who designate their ethnicity as "other" (i.e., who are Native American, Asian American, or from the Pacific or Caribbean Islands). A full 27.4 percent of these women have unsafe blood mercury levels. Every year as many as 94,000 babies are born in the United States with elevated blood mercury levels-levels high enough to leave them with irreversible brain damage - and as many as 231 children develop mental retardation, all as a direct result of exposure to mercury emissions from U.S. power plants.

\section{The Issue}

Mercury pollution has long been recognized as extremely harmful to humans and the environment. For example, fetal exposure to environmental mercury can impair human brain development, resulting in an array of negative consequences such as IQ loss ranging from 0.2 to 24 points, cerebral palsy, and mental retardation (i.e., an IQ below 70). ${ }^{1}$

Coal-fired power plants are the single largest emitters of mercury pollution in the United States, releasing roughly 48 tons every year. ${ }^{2}$ Coal naturally contains trace amounts of 
mercury, and the process of combustion causes this mercury to be released into the air. These mercury particles fall into lakes and streams, where they are converted to methylmercury before being consumed by the fish that humans and other animal species eat. An estimated 10 percent of American women of childbearing age have unsafe blood mercury levels, putting many children at risk of fetal exposure to environmental mercury. About 27.4 percent of women who designate their ethnicity as "other" (i.e., who are Native American, Asian American, or from the Pacific or Caribbean Islands) have unsafe blood mercury levels-nearly triple the national average. ${ }^{3}$

Mercury pollution from power plants is taking a devastating toll on childhood brain development. According to data from two studies, ${ }^{4}$ strict regulation of mercury emissions from U.S. power plants could prevent around 94,000 American babies every year from being born with elevated blood mercury levels_-levels high enough to leave them with irreversible brain damage. It could also prevent as many as 231 children from developing mental retardation every year.

\section{The Regulatory Delay}

Mercury poses a clear problem: Hundreds of thousands of children are born in the United States every year with elevated blood mercury levels because of mercury air pollution. Congress has provided a clear solution: Given the finding that mercury from power plants posed a threat to human health, the 1990 Clean Air Act Amendments required the EPA to drastically reduce mercury emissions from coal-fired power plants. By any reasonable estimate, this regulation should have been issued by 2000 at the latest. It's now 2009, and EPA has yet to act.

Below, we recount the disappointing sequence of events that has prevented EPA from regulating mercury in accordance with Congress' clear instructions. From this narrative, certain themes emerge — a lack of resources, industry pressure, and, most pernicious, rules with built-in delay.

\section{Congress Cocks the Hammer...}

Frustrated by EPA's lack of progress in addressing toxic air pollutants under the original Clean Air Act of 1970, Congress put regulation of these pollutants on the fast track when it amended the Clean Air Act in 1990. The Amendments gave special attention to the problem of mercury pollution from power plants.

These Amendments directed EPA to submit to Congress by November 1994 a series of preliminary reports on mercury pollution and alternative control strategies. If, after reviewing these reports and other relevant evidence, EPA determined that regulating power plant mercury emissions was "appropriate and necessary," the Amendments required the agency to adopt very strict technology-based regulations (a maximum achievable control technology or MACT standard). 
Working with reasonable diligence, EPA should have been able to complete a final MACT standard for mercury within a few years after 1994, when the last of the required reports should have been completed. At the very least, EPA should have been able to finish the MACT standard by November 2000, which was the catch-all deadline set by the Amendments for EPA to issue regulations for all toxic air pollutants.

\section{. . But EPA Can't Pull the Trigger on MACT}

EPA has always been plagued with inadequate resources, but the problem was especially acute during the Clinton Administration. The 1990 Clean Air Act Amendments directed EPA to implement an array of new programs, yet Congress never increased the agency's budget to reflect its increased workload. ${ }^{5}$ To make matters worse, the coal and power plant industries worked hard from the beginning to prevent EPA from regulating mercury emissions. One favored tactic was to attack EPA's science. By simply raising the question of whether we "know enough" about mercury's health effects, industry was able to put EPA on the defensive. Of course, it is always the case that more can be learned, and even those scientific conclusions about which we are most certain are always open to question- that is the nature of scientific inquiry. Nonetheless, EPA felt compelled to go to great lengths to answer these attacks. As a result, the agency fell further and further behind the timeline set up by the 1990 Amendments.

Industry began its attacks by criticizing the science in EPA's preliminary reports. EPA responded by holding back one report until new scientific studies became available ${ }^{6}$ and by putting some of the reports through a lengthy review process. ${ }^{7}$ Even after numerous independent reviews confirmed that the reports were supported by the "best available science," industry continued to pressure EPA to delay submitting them to Congress until better scientific evidence emerged. As a result, EPA did not submit the last of the reports until March 1998-almost four years after they were all due.

Even once the reports were finally done, EPA declined to make the "appropriate and necessary" finding, asserting that it needed to conduct more studies on emissions control technology. Six months later, industry allies in Congress managed to insert a rider into an appropriations bill ordering EPA to delay its "appropriate and necessary" finding even further- until after the National Research Council approved the science underlying one of EPA's reports. Another 21 months went by while EPA waited for approval from the Council, which was ultimately granted in July 2000. ${ }^{8}$ Finally, in December 2000, as President Clinton was packing up to leave the White House, EPA made the "appropriate and necessary" finding, six years after all the studies were supposed to have been completed.

\section{The Bush Administration Stomps on the Brake Pedal}

Soon after making the "appropriate and necessary" determination, EPA convened a high-level, multi-stakeholder group of advisors to work with agency staff on the MACT 


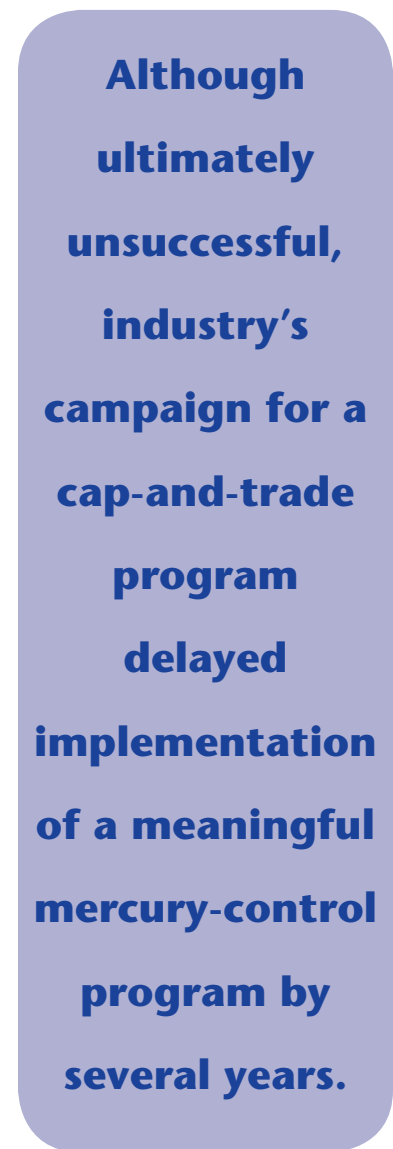

The Costs of Regulatory Delay years. standard. A court order required EPA to issue the standard by December 2003, and by the beginning of that year, the agency seemed poised to meet the deadline. Even manufacturers of emissions control technology began ramping up their production in anticipation of heightened demand.?

In spring 2003 though, EPA's progress came to a screeching halt, when the Assistant Administrator in charge of the Office of Air and Radiation, an EPA political appointee, gathered the relevant staff in his office and told them to abandon the work they had completed to date and adopt an entirely different approach to the issue. Under a creative interpretation of the statute—one that would later be struck down by a federal appeals court-EPA ignored the statute's directive to develop a MACT standard. Instead, EPA began developing a cap-and-trade program for mercury.

EPA managed to issue a proposed rule incorporating the new cap-and-trade approach in December 2003, just in time to meet the court-ordered deadline. Industry favored the cap-and-trade rule, in part because it imposed substantially weaker controls than a MACT standard would have. But the cap-and-trade rule was also highly favorable to industry in another, more subtle way: It had built-in delay provisions. The initial 38-ton cap would actually have no impact on mercury emissions at all, since power plants were slated to achieve that level of emissions reduction anyway as an ancillary benefit of another, unrelated clean air program. The cap would not shift to a more stringent 15 tons until 2018, but even then, it would not actually require meaningful reductions for another several years. Because the program allowed power plants to bank credits in the early years while the cap was lax and then use them later, EPA's own models showed that the 15-ton cap would not actually be met until after 2020 or perhaps as late as the 2030s. ${ }^{10}$

EPA adopted the cap-and-trade plan in a final rule, issued in 2005. But three years later, the whole scheme backfired (or so it seemed). In 2008, a three-judge panel for the D.C. Circuit Court of Appeals unanimously agreed that the cap-and-trade program violated the Clean Air Act's requirements and sent EPA back to square one to come up with a new rule. ${ }^{11}$ Now, nearly two decades after Congress directed EPA to regulate mercury emissions from power plants, those plants continue to operate free of federal controls. And while industry and its allies did not succeed in writing the toothless cap-and-trade rule into regulation, their campaign did manage to delay the implementation of a meaningful program by several more

\section{Postscript: America's Mercury Future}

In the vacuum left by EPA's interminable delay, 22 states have established their own regulations to control mercury emissions from power plants. ${ }^{12}$ Save for these state programs, however, U.S. power plants are free to pump unlimited amounts of mercury pollution into our air for the foreseeable future. 
In March 2009, the Obama EPA announced that it will resume development of a MACT standard and recently committed to completing the new regulation by $2011 .{ }^{13}$ Meeting this deadline will be challenging. Because the abrupt change in course toward a cap-andtrade program during the Bush years effectively buried the original MACT standard, the agency will need to redo much of its earlier work. For example, EPA announced on July 2, 2009, that it will need to collect more up-to-date data from power plants on their mercury emissions, since the most recent data are now 10 years old and no longer valid. ${ }^{14}$ Similarly, EPA will probably need to conduct new analyses of the state of the market for mercury control technology. This technology has greatly improved in recent years in response to the growing number of state programs for regulating mercury. As a result, EPA's old analyses have become outdated.

\section{The Costs of Delay}

With each year that EPA fails to take decisive action on power plant mercury emissions, the human and environmental costs pile up. The cost of EPA's inaction that has received the most attention is impaired childhood brain development. According to one study, as many as 637,000 children are born each year with elevated blood mercury levels — that is, blood mercury at levels shown to be associated with cognitive dysfunction including IQ loss and mental retardation. Because coal-fired power plants in the United States are responsible for roughly 15 percent of the mercury pollution to which these children are exposed, this study suggests that strict regulation of power plant mercury emissions could prevent around 94,000 American babies from being born with elevated blood mercury levels each year. ${ }^{15} \mathrm{~A}$ second study concludes that this strict regulation could also prevent as many as 231 children from developing mental retardation every year. ${ }^{16}$

The consequences of impaired brain development are often devastating. IQ loss—one common consequence of childhood brain damage — can adversely affect a child's behavior, memory, and ability to learn and communicate. Other common consequences of childhood brain damage include vision impairment, muscular control dysfunction, and problems with coordination. ${ }^{17}$ These adverse effects in turn can harm a child's ability to perform well in school, to make friends, and eventually to be a productive member of society. They also can take a large emotional toll on these children and their families. Imagine the humiliation a child experiences when he performs poorly in school or the anguish a parent might feel when she watches her child struggle with his schoolwork.

Nor are the human health consequences of mercury pollution limited to impaired childhood brain development. Mercury pollution has been linked to kidney disease, damage to the nervous system, and cardiovascular disease in adults. One recent study estimates that limiting power plant mercury emissions to 15 tons per year could prevent up to 380 fatal heart attacks and 210 non-fatal heart attacks each year. ${ }^{18}$

Certain groups, like Asian Americans and American Indian tribes, have been hit particularly hard by the human costs of EPA's inaction. For cultural and other reasons, Asian Americans 


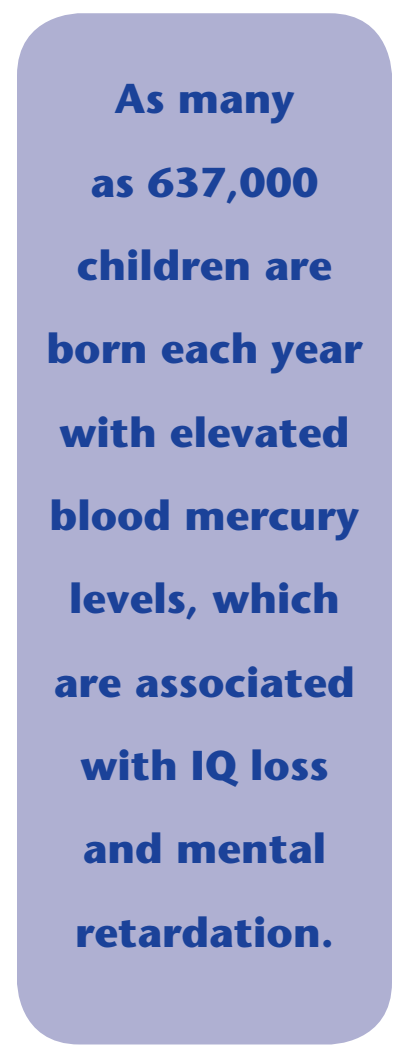

and American Indians tend to consume more fish than the general population, which increases their exposure to mercury pollution. As a result, the human health consequences of mercury pollution - particularly the worst cases — tend to fall disproportionately on these communities. For example, among the general population, mercury pollution is estimated to cause typical IQ losses of between 1.60 and 3.21 points. Among the Great Lakes Indian tribes, however, the estimate of typical IQ losses from mercury pollution ranges from 6.2 to 7.1 points. ${ }^{19}$

EPA was not unaware of the risks to these and other populations who consume large amounts of fish. But in the absence of emissions controls, EPA simply referred these groups to the relevant fish consumption advisories, suggesting that they reduce or curtail entirely their intake of several species of fish. ${ }^{20}$ For some people, however, avoiding the risks of mercury by ceasing fish consumption is not a realistic option. This concern is especially acute during these difficult economic times, as more and more people consider fishing as a way to put food on the table for themselves and their families. In this way, mercury pollution can impose costs on certain populations by increasing food insecurity.

Some groups also suffer unique cultural costs as a result of mercury pollution. Fishing is central to the culture of American Indian tribes like the Aroostock Band of Micmacs in Maine and is reflected in their ceremonies, language, and songs. To the extent that members of these tribes have had to stop consuming fish for health reasons, these cultural practices are not being passed on to the next generation and risk being lost forever. Similarly, when mercury pollution harms animal species like the loon and mink-which serve as important clan symbols for the Minnesota Chippewa Tribe-it is more than just an environmental cost for American Indians; it is also a serious affront to their tribal identity and dignity. ${ }^{21}$

Lastly, mercury pollution like that emitted from power plants produces significant environmental costs. This pollution can cause brain damage, reproductive system damage, behavioral abnormalities, and even death in birds and mammals that depend on fish, such as bald eagles, loons, kingfishers, osprey, otters, minks, and the endangered Florida panther. ${ }^{22}$

\section{In Sum}

The story of EPA's persistent failure to regulate power plant mercury emissions provides a stark and disturbing illustration of how regulatory delay can yield massive and indefensible human costs. Congress first told EPA to regulate toxic air pollutants like mercury in 1970. Two decades later, frustrated with EPA's slow progress, Congress gave the agency a specific directive to regulate mercury emissions from power plants and to get it done by the end of the decade at the latest. Now, nearly two decades after Congress's second directive, power plants continue to emit mercury into the air, free of federal controls. Meanwhile, tens of thousands of children are born each year with blood mercury levels high enough to cause irreversible brain damage that could have been prevented, hundreds die needlessly of heart attacks, and countless additional untold human and environmental losses continue to mount. 


\section{CASE STUDY: Ballast Water Discharges and Invasive Species}

In 1972, the Clean Water Act set ambitious goals for cleaning up the country's waters, requiring permits for discharges of a broad range of pollutants. Even though the ballast water routinely discharged by ships into harbors, lakes, and rivers contains biological pollutants clearly covered by the Act, in 1973, EPA issued a regulation exempting ballast water from the Act's permitting requirements. In the decades since, the rapid spread of the zebra mussel-an invasive species from Eastern Europe first brought by ships to Lake St. Clair in Michigan-has demonstrated the dramatic costs of inaction. In the past two decades, this invasive species has ravaged the waterways of 25 states and caused an estimated $\$ 1$ billion in damages each year, clogging pipes at power plants and sewage treatment plants and displacing native species. After a federal appeals court invalidated the 1973 exemption, EPA finally began requiring permits for the discharge of ballast water, but this action comes 20 years too late. Today zebra mussels are a permanent and costly nuisance in many freshwater ecosystems.

\section{The Issue}

While significant progress has been made in reducing conventional pollutants under the Clean Water Act, invasive species - a type of biological pollutant-have continued to infest native ecosystems and displace native species. What makes these pollutants so insidious is their permanence: Once established, invasive species are nearly impossible to eradicate and forever change native ecosystems. Aquatic invasive species spread through cargo-ship ballast water, which is taken up and discharged at ports along a ship's route. The water is stored on board in pool-sized tanks and helps balance a ship as it loads and unloads cargo.

No bigger than two inches and innocuously named, zebra mussels have spread to hundreds of water bodies around the country in the past two decades. These mussels are native to Eastern European waters and arrived in the United States in ballast water discharged into the Great Lakes. With no natural predators, they have aggressively established populations in many of the country's great waterways. Zebra mussels cause an estimated $\$ 1$ billion in losses annually by clogging water intake pipes at power plants, municipal water supplies, and other industrial facilities. Control measures, such as mechanical scrapers, chemical treatment, filtration devices, and physical barriers, are also costly, and no single measure is uniformly effective. In 1989, just one year after the mussels were discovered in Lake St. Clair, the town of Monroe, Michigan, lost its water supply for three days because a zebra mussel colony completely clogged an intake pipe. ${ }^{23}$

When Congress passed the Clean Water Act in 1972, it directed the fledgling EPA to regulate pollution of the nation's waters, including biological pollution. Had EPA followed this mandate - instead of issuing an explicit exemption for ballast water — the nation might have avoided the steep economic and environmental costs of this invasive species. 


\section{The Regulatory Delay}

The Clean Water Act prohibits "the discharge of any pollutant" into the nation's waterways without a permit, and defines "pollutant" broadly to include biological materials. When ships discharge ballast water, they discharge such biological materials and other pollutants into the water. Despite its clear statutory directive, in 1973 EPA issued a regulation exempting ballast water from the Act's permit requirement. ${ }^{24}$ In 2008, a federal appeals court unanimously struck down this regulation, holding that it violated the plain language of the Clean Water Act: to prohibit the discharge of any pollutant without a permit. ${ }^{25}$ Indeed, the court found the statutory violation so clear that it noted "the EPA does not seriously contest this conclusion."26

When it issued the 1973 regulation, EPA was in its infancy and charged with an ambitious agenda. An EPA official said that at that time the agency was so overwhelmed with "higher priority situations ... vessels were not important to the overall scheme of things at that time." ${ }^{27}$ The exemption was attractive to the struggling young agency because it would "dramatically reduce administrative costs." ${ }^{28}$ The EPA tried to justify its inaction in the face of a clear statutory directive by asserting that ballast water discharges "generally cause little pollution" anyway. The agency further maintained that the exemption was an attempt to avoid duplicative regulation when other federal bodies — namely the Coast Guard-were likely to be more effective and efficient than EPA. Regulations on ballast water discharges issued by the Coast Guard in 1998 were purely voluntary, however, and proved ineffective at addressing the problem. For decades after it initially declined to regulate biological pollution in ballast water, EPA fell into the easy bureaucratic inertia of inaction. The agency assumed that since Congress knew about the exemption and did not legislatively reverse it, the approach must be permissible despite the CWA's explicit language to the contrary.

In 1973, it may have been plausible to think that ballast water discharges "generally cause little pollution." However, by the mid-1990s, it was apparent that invasive species-and zebra mussel in particular-were destroying native ecosystems and pushing native species to extinction. Congress, state governments, and the president realized the severity of the problem. Congress addressed the problem in part by passing the National Invasive Species Act of 1996, authorizing the U.S. Coast Guard to establish ballast water discharge guidelines. As noted above, however, these guidelines were purely voluntary when first issued and had limited effect. ${ }^{29}$ President Bill Clinton attempted to address the problem in 1999 with an executive order requiring federal agencies to "use relevant programs and authorities" to "prevent the introduction of invasive species," and prohibiting federal agencies from authorizing, funding, or undertaking activities that are likely to cause or promote the introduction or spread of invasive species. ${ }^{30}$ But despite this prodding, EPA did not revisit its exemption.

While EPA dallied, coastal and Great Lakes states developed their own ballast water regulations. For example, California's Marine Invasive Species Act requires ships over 300 tons traveling from outside the Pacific Coast Region to discharge ballast water at least 200 
nautical miles from shore in water no less than 2,000 meters deep. Washington and Oregon have similar legislation modeled after this act. A federal appeals court recently upheld the Michigan ballast water regulations that require oceangoing vessels to obtain a permit from the state, ${ }^{31}$ and other Great Lakes states have begun the process of adopting similar regulations. ${ }^{32}$

After the federal appeals court invalidated EPA's ballast water exemption in 2008, the agency finally began regulating ballast water by requiring a permit for discharge, 20 years after the first zebra mussels were found in the United States. ${ }^{33}$ However, advocacy groups and the Michigan Department of Environmental Quality point out that the permit conditions are weak and give "the appearance the agency is avoiding reaction from the shipping industry." 34 Great Lakes states, such as New York, have already passed more stringent controls to supplement EPA's conditions and to better protect their waters. ${ }^{35}$ Whether this new program will be effective remains to be determined, but critics seem skeptical.

\section{The Costs of Delay}

Decades of inaction by EPA have been both economically and ecologically costly. Zebra mussels and quagga mussels, a similar invasive species introduced from ballast water, together cost approximately $\$ 1$ billion annually in losses from clogged water pipes to expensive equipment installed to clean-up and prevent infestations. Colonies of zebra mussels can reduce the diameter of a water pipe by two-thirds, constricting water flow and reducing water intake for equipment essential to any facility that withdraws water: power plants; municipal water plants; and other industries. ${ }^{36}$ The costs of preventing and destroying zebra mussel colonies have been astronomical and are undoubtedly passed along to the public. Ecologically, the impact of zebra mussel infestations has also been dramatic, though harder to quantify. The mussels attach to and smother native species with hard shells and fundamentally alter the food web of freshwater ecosystems.

Since they were first discovered in the Great Lakes, zebra mussels have spread to 25 states. While many of the infestations are connected to the tributaries and waterways of the Great Lakes, zebra mussels have been found as far west as Colorado, Utah, and California. For western states such as California that rely heavily on hydropower, a permanent infestation could spell doom for the industry. At one power plant in Michigan, the colony density measured as high as 700,000 zebra mussels per square meter.

The U.S. Fish and Wildlife Service estimates that for the power industry and water facilities in the Great Lakes region, the clean-up and damage cost associated with zebra mussels will be $\$ 5$ billion between 2000 and 2010. At the James A. Fitzpatrick Nuclear Power Plant in New York, the initial installation cost for a chemical treatment system to prevent future infestations was $\$ 300,000$, in addition to between $\$ 60,000$ and $\$ 80,000$ in annual operating costs. Zebra mussels have not yet established colonies in Florida, but one study estimates that if they do, a statewide infestation could cost $\$ 244$ million in losses over a 20 -year period.
In 1989, just

one year after

the mussels

were discovered

in Lake St.

Clair, the town

of Monroe,

Michigan, lost

its water supply

for three days

because a zebra

mussel colony

completely

clogged an

intake pipe. 
Economic damages are not limited to power and other water-dependent industries. The weight of zebra mussel colonies on navigational buoys causes them to sink, and colonies cause corrosion of wooden docks, as well as steel and concrete pilings, undermining their structural integrity. ${ }^{37}$ Sharp and jagged zebra mussel shells litter beaches, injuring recreational beach-goers, and decaying carcasses mar a day at the beach with noisome odors.

While the environmental costs may not be easily quantifiable, they are no less significant. Ecologists have declared invasive species to be the second biggest threat to the natural environment, behind only habitat loss and degradation. Transplanted to new surroundings, invasive species have no natural competitors or predators to hold their populations in check. As a result, they proliferate exponentially and aggressively destroy native ecosystems by physically displacing native species and consuming resources. Once established, invasive species cannot be easily eradicated without highly toxic methods that would also wipe out native species.

Zebra mussels are prolific breeders: A single female can produce up to one million eggs, 20 percent of which survive to adulthood. Mobile during their larval stage, they float through waterways and tributaries before attaching onto hard structures as adults. As filter feeders, zebra mussels have dramatically altered the food webs in Lake Erie. In some parts, they have increased water clarity to 30 feet from 6 inches by consuming nearly all the algae in the water. That dramatic change may please swimmers, but it also alters the entire food chain to the detriment of native fish and aquatic species and ultimately impacts fishermen and wildlife that depend on native fisheries. Unlike other mollusks, zebra mussels also attach to native clams and other mollusks, eventually smothering them and causing precipitous declines in their populations. One report predicts that zebra mussels will cause the extinction of up to 140 native species of mussels by $2012 .{ }^{38}$

\section{In Sum}

Hamstrung by inadequate resources, EPA made an initial decision not to regulate ballast water, despite a clear statutory directive to do so. In the decades that followed, that decision proved costly as the evidence mounted that zebra mussels brought to U.S. waters in ballast water were taking a devastating economic and ecological toll. The agency remained locked in bureaucratic inertia from which it did not emerge until 2008, when a federal court ordered the agency to take action. Meanwhile, the zebra mussel infestation imposed a billion-dollar price tag annually on industry and government, and now the mussels' permanence in the nation's waterways is all but given. EPA's long-delayed regulation of ballast water has come too late to have much hope of reversing the zebra mussel problem. But we can hope that it will prevent the introduction of the next invasive species. 


\section{CASE STUDY: Collapsing Cranes}

In 1971, the Occupational Health and Safety Administration issued regulations for the use and operation of cranes, derricks, and other heavy machinery at construction sites. Nearly four decades later, OSHA has not updated this rule despite vast changes in technology and work processes. Beginning in the mid-1990s, industry itself began petitioning OSHA for stronger and more comprehensive regulations and in 2004 a committee of industry, labor, and government representatives reached agreement on a draft proposed rule. But five years later, this rule is still trapped somewhere in OSHA, waiting to be issued. Meanwhile, by OSHA's own estimates, 89 crane-related deaths and 263 crane-related injuries occur each year. Implementing the draft rule would reduce these numbers by 59 percent. In other words, every year the rule continues to sit on a desk while OSHA remains understaffed, under-resourced and over-stretched, 53 people die and another 155 are injured unnecessarily.

\section{The Issue}

The headlines are uncomfortably familiar: "Crane Collapse in Houston Kills 4," describing the 2008 collapse of a 30-story-tall crane that smashed into the ground, lifting nearby workers off their feet in Texas where neither state nor federal regulations require crane operators to be licensed; "Crane Topples in Manhattan," detailing the worst construction accident in the history of New York City when a 20 -story-tall crane crashed into surrounding buildings, killing six construction workers and a tourist bystander; and "Two Workers Are Killed in Miami Crane Accident," recounting the deaths of two construction workers and injuries to five others when a seven-ton section of a crane crashed through the roof of the nearby project's safety office. ${ }^{39}$

The numbers are disturbingly high: An estimated 89 crane-related deaths each year with even more injuries to bystanders and rescue workers and millions of dollars in insurance payments, lawsuits, and project delays.

The regulations are indefensibly outdated: Despite technological leaps in construction machinery, OSHA has not updated the standards or requirements for operating cranes and other heavy equipment since 1971, nearly four decades ago.

\section{The Regulatory Delay}

The technological landscape of 1971 would be virtually unrecognizable today: offices ran on typewriters and carbon-copies; most phones were still rotary dialed; and engineers wore slide rules on their belts. This was the year that OSHA adopted the regulation for the operation of cranes, derricks, and other heavy machinery that remains in place today. Nearly four decades later, just as cell phones, laptop computers, and pocket calculators have 


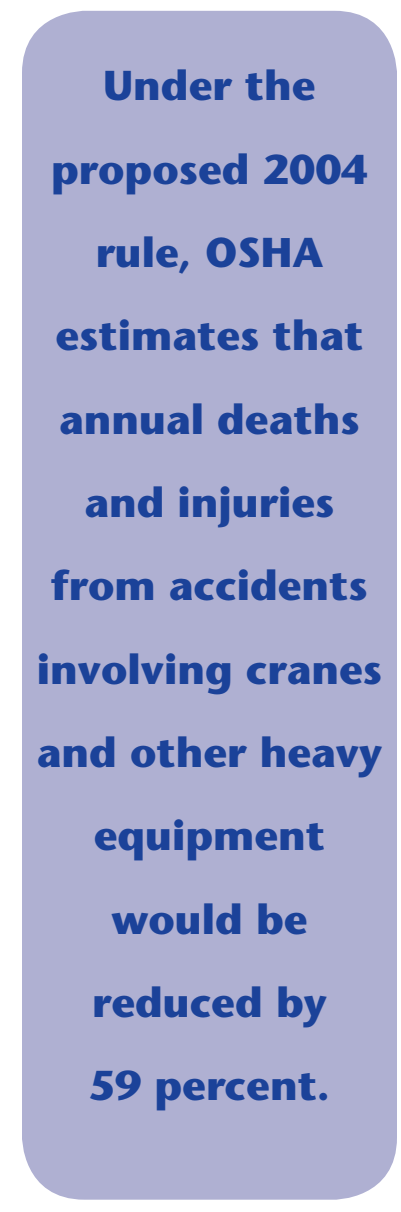

revolutionized the technological landscape, the technology that operates cranes, derricks, and other heavy machinery at construction sites looks nothing like it did in 1971. Unfortunately for today's crane operators and construction workers, the safety protections in their workplaces are as outdated as slide rules and carbon paper. ${ }^{40}$

Operating a crane in the 21st century is a highly technical and complex enterprise, involving sophisticated electronics and computers and requiring specific skills and experience to avoid accidents. The major causes of crane-related deaths and injuries are electrocution, improper assembly and disassembly, general equipment failure, and crane tip-over. But underlying these causes is a more basic problem: a lack of qualification and training for operators, supervisors, and crewmembers. The old rule, written for a different era, is hopelessly outdated, particularly with respect to the training and certification of personnel.

By the mid-1990s, things were so bad that industry itself was calling for updated federal regulations to reduce the number of crane-related deaths and to address the underlying causes of those accidents. In 1998, OSHA, recognizing the need for an updated standard, established a workgroup to make recommendations for updates to the cranes and derricks rule. Four years later, there was still no rule, but OSHA announced that it would seek a collaborative process involving industry stakeholders and representatives from all interested parties $^{41}$ to negotiate an updated federal standard. The committee began its meetings in 2003 and worked under the premise that, if it could agree on a draft rule, OSHA would publish and finalize the draft as its rule. ${ }^{42}$ Within a year, the committee achieved consensus on a draft rule, which it submitted to OSHA in July 2004.

The draft rule fills many gaps left by the 1971 standards. It directly addresses the underlying problem of inexperience by requiring operators, inspectors, and assembly and disassembly workers to be certified. The rule accounts for the many technological developments since 1971 by regulating new safety and operating equipment, mandating certain protocols for failures of commonly used technologies, and permitting greater flexibility to select equipment made safer by new technologies. The draft rule also addresses electrocution, a major cause of death, by specifying the minimum distance between equipment and active power lines. ${ }^{43}$

Following completion, the draft rule stalled at OSHA for four years, a victim of stretched resources and competing priorities. Noah Connell, the director of OSHA's Office of Construction Standards and Guidance, explained that finalizing the proposed rule was "quite simply, an enormous undertaking." ${ }^{44}$ He described the process of writing the background and justification as "very time-consuming," requiring frequent consultation with other departments on technical questions. When addressing the internal delay, Connell aptly described the signs of an under-resourced and over-stretched agency:

You know, the timelines, it's very difficult to predict these dates. You know, we don't work independently. We work with a number of different agencies within OSHA. Those different parts of OSHA have projects other than 
our project and so inevitably there is some competition of resources and, you know, the agency as a whole has been working on many, many projects concurrently. ${ }^{45}$

Not until June 2008-four years after the rulemaking committee reached consensus on a new draft rule- did the proposed rule make it to the White House for final scrutiny. In August 2008, the Office of Management and Budget gave its approval and six weeks later, in October 2008, OSHA published the proposed rule in largely the same form as negotiated by the committee four years earlier. ${ }^{46}$ After a series of extensions, the comment period finally ended in June 2009, but to date OSHA has still not issued the final rule. Recently, acting OSHA Director Jordan Barab again attributed the delay to an over-stretched agency, emphasizing the complexity and immensity of the new rule. Barab estimated that OSHA would finalize the new cranes and derricks rule "some time next year," which means in 2010, nearly four decades after the existing rule was issued and six years after the draft rule was completed. ${ }^{47}$

Notably, the new rule has consistently enjoyed broad-based support. Throughout the delay period, industry representatives, members of the rulemaking committee, OSHA representatives, ${ }^{48}$ and Members of Congress have all expressed overwhelming support for the draft rule and have urged final approval. When OSHA first publicly acknowledged the need to update the rule in 1999, it was in response to repeated requests by industry representatives. In July 2008, a group of senators wrote an open letter to Secretary Chao, calling the regulatory delay_-both the failure to update the rule since 1971 and the four-year delay in submitting the draft rule to the OMB — "unfathomable."

\section{The Costs of Delay}

By OSHA's own estimates, 89 crane-related deaths ${ }^{49}$ and 263 worker injuries ${ }^{50}$ occur each year at construction sites. Under the proposed rule, OSHA estimates that 59 percent of these deaths and injuries could be avoided. In short, every year that goes by without the new rule in place another 53 people die and 155 are injured in accidents that could and should have been prevented. ${ }^{51}$

Accidents involving cranes, derricks, and similar machinery are not only costly in terms of human lives lost but in financial terms for employers and project owners. Take, for example, Miller Park, home of the Milwaukee Brewers baseball team in Milwaukee, Wisconsin. OSHA estimates that the total cost of the project will approach $\$ 1$ billion, including the cost of construction, lawsuits, and penalties, after a crane accident killed 3 construction workers in 1999. ${ }^{52}$ The workers died when a collapsing heavy-lift crane struck their elevated platform. The crane, nicknamed Big Blue and capable of lifting 1500 tons, was being used to place sections of the Park's roof weighing over 450 tons. Because of the crane accident, the stadium construction fell one year behind schedule and failed to open 


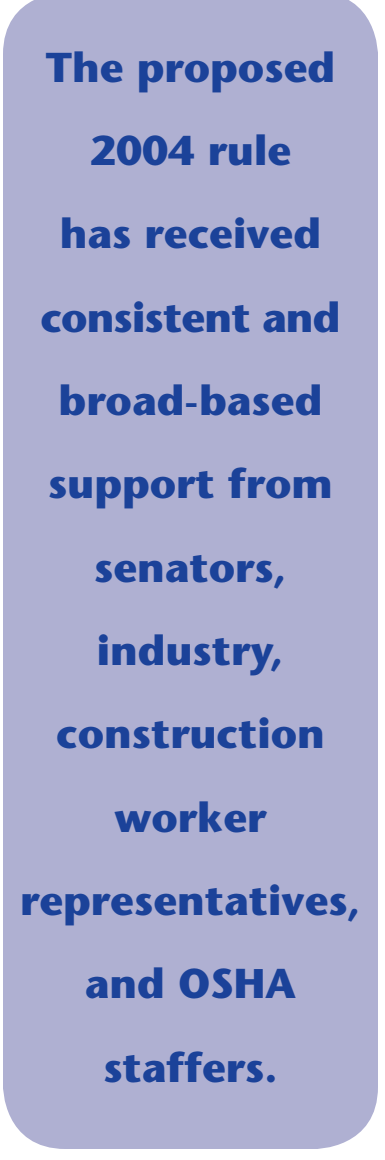

in time for the 2001 baseball season. The cost of the construction alone was 28.5 percent more than budgeted, not including the $\$ 100$ million in repair costs covered by insurance and the millions of dollars in civil and punitive damages that a jury awarded to the workers' beneficiaries.

\section{In Sum}

With each year that passes without an updated rule governing cranes and derricks at construction sites, another 89 people die and another 263 are injured. Behind each statistic is a compelling story - a new father, a newlywed, a tourist in town for the weekend. But what makes these deaths and injuries particularly tragic is that more than half were entirely preventable. The need for a new rule has been apparent for decades, and for the past five years a new rule has been ready to go, drafted and agreed upon by all relevant stakeholders. Yet it remains lost in the hallways of OSHA — an agency overwhelmed by responsibilities and drastically under-staffed and under-resourced. Meanwhile, the costs of delay continue to climb. 


\section{Conclusion}

As these three case studies illustrate, regulatory delay has become commonplace at the protector agencies - the norm in Washington, despite the manifest health, safety, and environmental problems the delays cause. Time and time again, protector agencies like EPA and OSHA unjustifiably delay issuing new regulations or updating old ones, often in clear violation of the statutes under which they operate.

At least three lessons are clear from the foregoing case studies. First, no single measure can capture the costs of regulatory delay. In some cases, they are measured in terms of human health, such as the children born with elevated blood mercury levels as a result of EPA's delay in issuing a mercury rule for power plants. In other cases, they are measured in terms of preventable deaths and injuries, such as the dozens of construction workers and innocent bystanders killed or injured as a result of OSHA's delay in updating regulations for the use and operation of cranes and derricks. In still other cases, these costs are measured in terms of ecological damage and disruption - the full scope of which scientists do not even yet understand—such as the countless animal species that have been harmed as a result of EPA's delay in properly regulating the spread of invasive species through ballast water discharges or its delay in regulating mercury from power plants. And finally, there are some cases where the costs can be measured in monetary terms, such as the damage to power plant water intake pipes that have resulted from EPA's failure to prevent the spread of zebra mussels through ballast water discharges.

Second, regulatory delay has far-reaching consequences, threatening the health and safety of diverse populations, harming business interests and workers, and damaging the environment. Vulnerable populations, including children, Asian Americans, and American Indians, are particularly hard hit by the mounting costs of EPA's delay in regulating power plant mercury emissions. More and more construction workers suffer the consequences of OSHA's delay in issuing an updated rule on cranes and derricks. The health of freshwater ecosystems throughout the United States worsens, as many are permanently altered by the spread of zebra mussels due to EPA's delay in establishing a regulatory program to prevent the introduction of invasive species through ballast water discharges. Also because of EPA's delay on ballast water, power plants bear the growing costs of unclogging their water intake pipes of zebra mussels rather than directing their resources toward controlling their harmful emissions.

Finally, from these case studies, it is clear that the costs of regulatory delay tend to remain hidden from public view. Whether it is children born with elevated blood mercury levels, injured or killed construction workers, or clogged water intake pipes, these costs often accrue gradually over time. Individually, these costs might attract some fleeting public and media attention, but collectively they are rarely understood as the interconnected results of a single delay in regulatory action by a particular agency. The fact that they can occur without much notice, despite their severity and extensiveness, is part of what makes the costs of regulatory delay so insidious. 
Unfortunately, regulatory opponents have worked hard to ensure that the costs of regulatory delay remain hidden. As the case studies make clear, the goals of regulatory opponents are served not just when they kill or weaken regulations, but also when they delay them for a considerable amount of time. Accordingly, when it comes to measuring the performance of the U.S. regulatory system, they have sought to skew the focus towards the costs of regulation, rather than towards the cost of regulatory delay.

It is nevertheless crucial to cast a spotlight on these often-hidden costs. Without a clear understanding of how regulatory delay affects real people and the environment, it is impossible to obtain a complete picture of the invaluable role that the U.S. regulatory system plays in our society. Without this clear understanding, it is also impossible to have an open and honest discussion over what needs to be done to reinvigorate these agencies so that they can go about the business of protecting people and the environment.

The White House Office of Management and Budget (OMB) can play an instrumental role in drawing greater attention to the costs that result from regulatory delay by documenting these costs in its annual Report to Congress on the Benefits and Costs of Federal Regulations. As explained above, these annual reports have helped reinforce the perception that regulatory delay is cost-free by documenting and aggregating the costs and benefits of regulatory action, while ignoring the costs of delayed regulatory action. OMB should expand these reports to include a description of the costs of delayed regulatory action so that they provide a more accurate picture of the value of regulation.

The problem of regulatory delay — and the profound costs that it generates—will not be solved easily. At a minimum, we need to ensure that the protector agencies receive the resources they need to carry out their respective statutory missions. Beyond that, we need to continue exploring other ways to reinvigorate the protector agencies so they can carry out these missions in as timely a manner as possible. 


\section{End Notes}

1 Leonard Trasande et al., Mental Retardation and Prenatal Methylmercury Toxicity, 49 Ам. J. Indust. MED. 153, 153 (2006) [hereinafter Trasande et al., Methylmercury Toxicity]; NE. States for Coordinated Air Use Mgmt., Economic Valuation of Human Health Benefits of Controlling Mercury from U.S. Coal-Fired Power Plants (2005) [hereinafter Economic Valuation]; Office of Air Quality Planning \& Standards \& Office of Research \& Dev., U.S. Envtl. Prot. Agency, 5 Mercury Study Report to Congress: Health Effects of Mercury and MercuRy Compounds (1997), available at $\mathrm{http}: / /$ www.epa.gov/ttn/caaa/t3/reports/volume5.pdf [hereinafter Mercury Study Report].

2 U.S. E.P.A., Fact Sheet-EPA's Clean Air Mercury Rule, http://www.epa.gov/mercuryrule/ factsheetfin.htm (last visited Aug. 10, 2009).

3 Kathryn R. Mahaffey et al., Adult Women's Blood Mercury Concentrations Vary Regionally in the United States: Association with Patterns of Fish Consumption (NHANES 1999-2004), 117 ENVTL. Health Persp. 47 (2009).

4 Leonardo Trasande et al., Applying Cost Analyses to Drive Policy That Protects Children: Mercury as a Case Study, 1076 Ann. N.Y. ACAD. SCI. 911, 916, 919 (2006) [hereinafter Trasande et al., Applying Cost Analyses]; Trasande et al., Methylmercury Toxicity, supra note 1, at 153.

5 Sidney Shapiro \& Rena Steinzor, The People's Agents: Reviving Government Protection of Health, Safety, and the EnVironment (forthcoming 2009).

6 Michael Tighe, Pressure to Release Mercury Report Rises, L.A. Times, June 22, 1997, at 18; Dieter Bradbury, Coal-Fired Power Plants Spew Mercury But Avoid Crackdown, Portland Press Herald, Sept. 29, 1997, at 1A.

7 Tighe, supra note 6.

8 John Myers, Scientists Back EPA Mercury Regulations; Coal-Fired Power Plants Could See Action, Duluth News-Trib., July 16, 2000, at 3D.
9 See, e.g., Clean Air Act Advisory Committee, Meeting Summary, June 24, 2004, 4 (Statement of Timothy Johnson, Corning Inc.) (“[A]bout 10 years ago Corning Incorporated invented an absorbent for mercury control in coal fired power plants. EPA completed a technical review of mercury abatement about 10 years ago based on these power plants in Japan and Germany, and had concluded that mercury control costs less than $1 / 10$ to $1 / 2$ of a cent per $\mathrm{kW}$ hour. When the promise for a mercury regulation faded away 10 years ago, Corning Incorporated dropped the mercury absorbent technology, stopped the technical symposiums and shifted resources to other pollution controls."), available at $\mathrm{http} / / / \mathrm{www} . e p a . g o v / \mathrm{oar} / \mathrm{caaac} /$ pdfs/062404meetingsummary.pdf.

10 U.S. Envtl. Prot. Agency, Technical Support Document: Methodology to Generate Deposition, Fish Tissue Methylmercury Concentrations, and Exposures for Determining EfFectiveness of Utility Emission Controls 3, Tables 1.1 and 1.2 (2005), available at http://www.epa.gov/ttn/ecas/regdata/Benefits/ Final_Effectiveness.pdf (figures for emissions reductions presented in $\mathrm{kg} / \mathrm{year}$; authors' conversions); James E. McCARThy, Mercury Emissions from Electric Power Plants: An Analysis of EPA's CAP-And-Trade Regulations 7-8 (CRS Report RL32868, Apr. 15, 2005),

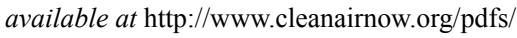
crsrptrule415.pdf.

11 New Jersey v. EPA, 517 F.3d 574 (D.C. Cir. 2008).

12 James E. McCarthy, Mercury Emissions from Electric Power Plants: States are Setting StRicter Limits 2 (CRS Report RL33535, Feb. 22, 2007), available at http://ncseonline.org/ NLE/CRSreports/07March/RL33535.pdf.

13 Cheryl Hogue, Power Plant Pollution, Chemical \& EngineERING News, July 27, 2009, at 42, 44.

14 Agency Information Collection Activities: Proposed Collection; Comment Request; Information Request for National Emission Standards for Coal- and Oil-fired Electric Utility Steam Generating Units, 74 Fed. Reg. 31,725 (July 2, 2009).

15 Trasande et al., Applying Cost Analyses, supra note 4 , at 916,919

16 Trasande et al., Methylmercury Toxicity, supra note 1 , at 153 .

17 Economic Valuation, supra note 1, at 26-37.

$18 \quad$ Id. at 168.
19 Catherine A. O'Neill, Environmental Justice in the Tribal Context: A Madness to EPA's Method, 38 ENvTL. L. 495, 531 (2008).

20 Proposed National Emissions Standards for Hazardous Air Pollutants; and, in the Alternative, Proposed Standards for Performance for New and Existing Stationary Sources: Electric Utility Steam-Generating Units; Proposed Rule, 69 Fed. Reg. 4652, 4709 (Jan. 30, 2004).

21 O'Neill, supra note 19, at 496-97, 509-13.

22 Mercury Study Report, supra note 1, at 3-43 to $3-45$.

23 Great Lakes Sci. Ctr., U.S. Geological Survey, Zebra Mussel, http://www.glsc. usgs.gov/main.php?content=research invasive_zebramussel $\&$ title $=$ Invasive $\% 20$ Invertebrates $0 \&$ menu=research_invasive invertebrates (last visited Aug. 18, 2009).

2440 C.F.R. $\S 122.3$ (2009) (exempting from the NPDES permit requirement "any . . . discharge incidental to the normal operation of a vessel").

25 Nw. Envtl. Advocates v. U.S. E.P.A., 537 F.3d 1006 (9th Cir. 2008).

26 Id. at 1022.

27 Id. at 1012.

28 National Pollutant Discharge Elimination System, 38 Fed. Reg. 13528 (May 22, 1973).

29 In 2004, the Coast Guard's guidelines became mandatory.

30 Exec. Order No. 13,112, 64 Fed. Reg. 6183 (Feb. 3, 1999).

31 The Michigan Department of Environmental Quality will issue a permit only if a ship can demonstrate that it will not discharge ballast water or will use environmentally sound technology and methods to prevent introduction of aquatic invasive species. 2005 Mich. Pub. Acts 33, available at http://www.legislature. mi.gov/documents/2005-2006/publicact/ pdf/2005-PA-0033.pdf.

32 Great Lakes Comm'n, Summary of Great Lakes State Ballast Water Legislation (July 2008), http://www.glc.org/advocacy/documents/HR2830-Summary-Fact-Sheet-April-08.pdf.

33 The regulations became effective on February 6, 2009.

34 Mich. Dep't of Envtl. Quality, Comments on EPA's Vessel General Permit (July 29, 2008), http://www.glelc.org/files/michigan-ballastwater-permit-comments.pdf. 


\section{End Notes}

35 Port of Oswego Authority v. Grannis, 2009 WL 1606015 (N.Y. Sup. Ct.) (upholding the New York Department of Environmental Protection's additional, more stringent ballast water discharge conditions).

36 U.S. Geological Survey, NAS - Nonindigenous Aquatic Species: Factsheet, http://nas.er.usgs. gov/queries/FactSheet.asp?speciesID=5 (last visited Aug. 18, 2009) [hereinafter Factsheet]; Brian Meyer, Zebra Mussels Clog City's Water Intake Pipe, Buffalo News, July 21, 2009.

37 Factsheet, supra note 36.

38 Brief for Natural Res. Def. Council as Amicus Curiae Supporting Respondents, Port of Oswego Authority v. Grannis, 2009 WL 1606015 (N.Y. Sup. Ct.) (No. 0010296/2008).

39 Crane Collapse in Houston Kills 4, USA Today, July 18, 2008; Carla Baranauckus, Crane Topples in Manhattan, N.Y. Times, Mar. 15, 2008; Damien Cave, Two Workers are Killed in Miami Crane Accident, N.Y. Times, Mar. 26, 2008.

40 OSHA did amend it twice-in 1988 and 1993 - but the amendments failed to address technological advances, operator certification, or employee training. These amendments clarified the conditions under which employees could be hoisted on personnel platforms and required certain safe distances from equipment, respectively.

41 The final committee members represented manufacturers and suppliers, employers, labor organizations, training and operator testing groups, power line owners, and insurance companies. See Safety Standards for Cranes and Derricks, 68 Fed. Reg. 39877, 39879 (proposed July 3, 2003) (to be codified at 29 C.F.R. pt. 1926).
42 Susan Podziba, Op-Ed., Safety Starts at the Top, N.Y. Times, June 12, 2008.

43 Linda Levine, Worker Safety in the Construction Industry: The Crane and Derrick Standard 12 (CRS Report RL34658, Nov. 21, 2008), available at http://fas.org/sgp/crs/misc/RL34658.pdf.

44 Occupational Safety \& Health Admin., U.S. Dep't of Labor, Advisory Committee on Construction Safety and Health, Meeting Transcript, Jan. 24, 2008, available at http://www.osha.gov/doc/accsh/transcripts/ accsh_012408.html.

${ }^{45} I d$.

46 During the public comment period, OSHA received initial requests to extend the original deadline for comments. Then, OSHA received requests to hold an informal public hearing. Cranes and Derricks in Construction, 74 Fed. Reg. 4363, 4364-65 (Jan. 26, 2009). OSHA held the hearing in March 2009 and added two post-hearing comment periods that ended in June 2009.

47 National Advisory Committee on Occupational Safety and Health, Meeting Transcript, July 15, 2009, available at http:// www.regulations.gov/ search/Regs/home.html\#documentDetail?R=0900 006480a000fa.

48 Levine, supra note 43.

49 Cranes and Derricks in Construction, 73 Fed. Reg. 59714, 59884 (proposed Oct. 9, 2008) (to be codified at 29 C.F.R. pt. 1926).
50 Mike Hall, OSHA's Four-Year Delay on Crane Safety Standard Highlighted in Wake of N.Y. Deaths, AFL-CIONOWBLOG, Mar. 20, 2008, http:// blog.aflcio.org/2008/03/20/oshas-four-yeardelay-on-crane-safety-standard-highlighted-inwake-of-ny-deaths/ (last visited Aug. 18, 2009). There are several estimates on the number of deaths and injuries per year related to crane and derricks accidents. The estimates depend on which industries are counted - construction, manufacturing, and mining suffer the most fatalities - and how the cause of death is attributed.

51 Cranes and Derricks in Construction, 73 Fed. Reg. 59714, 59884 (proposed Oct. 9, 2008) (to be codified at 29 C.F.R. pt. 1926).

52 Occupational Safety \& Health Admin., U.S. Dep't of Labor, The Great American Ballpark, http://www.osha.gov/dcsp/success_stories/ compliance_assistance/abbott/stadium construction.html (last visited Aug. 18, 2009).

\section{The Costs of Regulatory Delay}




\section{About the Authors}

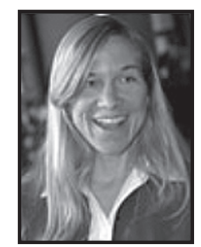

Catherine A. O'Neill is a Member Scholar of the Center for Progressive Reform and an Associate Professor of Law at Seattle University School of Law. She has worked on issues of environmental justice with various tribes, advisory committees, and grassroots environmental justice groups. Professor O’Neill was recently a member of the technical advisory board for the Swinomish Indian Tribal Community's four-year study, "Bioaccumulative Toxics in Native Shellfish." Professor O’Neill earned her J.D. from the University of Chicago and was a Ford Foundation Graduate Fellow at Harvard Law School. She has published numerous articles in the areas of environmental justice and environmental policy, many of which have been excerpted in casebooks, anthologies, and other collections.

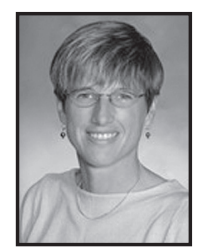

Amy Sinden is a Member Scholar and a Director of the Center for Progressive Reform, and an Associate Professor of Law at the Temple University Beasley School of Law in Philadelphia. Professor Sinden graduated summa cum laude from the University of Pennsylvania Law School in 1991. Before joining the Temple Law faculty in 2001, Professor Sinden served as senior counsel for Citizens for Pennsylvania's Future and a staff attorney with Earthjustice. She has written extensively in the area of environmental law and regulatory analysis. Her recent academic writings have criticized the misuse of economic theory in environmental law and have analyzed the application of classical human rights norms to environmental conflicts.

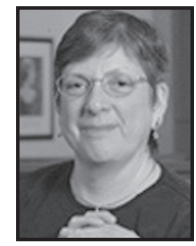

Rena Steinzor is the President and a Director of the Center for Progressive Reform and a Professor of Law at the University of Maryland School of Law, with a secondary appointment at the University of Maryland Medical School Department of Epidemiology and Preventive Medicine. Professor Steinzor received her B.A. from the University of Wisconsin and her J.D. from Columbia Law School. She joined the faculty of the University of Maryland School of Law in 1994 from the Washington, D.C., law firm of Spiegel and McDiarmid. From 1983 to 1987, She was staff counsel to the U.S. House of Representatives' Energy and Commerce Committee's subcommittee with primary jurisdiction over the nation's laws regulating hazardous substances. Professor Steinzor has published widely in the areas of environmental federalism, the implications of industry self-regulation on the protection of the environment and public health, and so-called "market based" alternatives to traditional regulation. Her most recent book, Mother Earth and Uncle Sam: How Pollution and Hollow Government Hurt Our Kids was published by the University of Texas Press in December 2007.

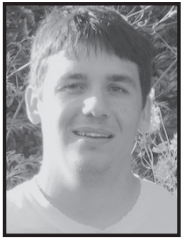

James Goodwin works with CPR's "Clean Science" and "Government Accountability" issue groups. Mr. Goodwin joined CPR in May of 2008. He earned his B.A. in Political Science from Kalamazoo College, his J.D. (with a certificate in environmental law) from the University of Maryland School of Law, and his M.P.P. (with a concentration in environmental policy) from the University of Maryland School of Public Policy. Prior to joining CPR, Mr. Goodwin worked as a legal intern for the Environmental Law Institute and EcoLogix Group, Inc. He is a published author with articles on human rights and environmental law and policy appearing in the Michigan Journal of Public Affairs and the New England Law Review.

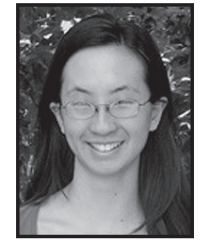

Ling-Yee Huang is a Policy Analyst with the Center for Progressive Reform. She graduated cum laude from Rice University with a B.A. in biology and received a Rotary Ambassadorial Scholarship to study international law at the University of Kent in Brussels, Belgium, where she received an L.L.M. with distinction. Ms. Huang received her J.D. cum laude from the University of Florida Levin College of Law. During law school, she published articles in the University of Denver Water Law Review, the Florida Journal of International Law, and the Cardozo Law Review. 
To see more of CPR's work or to contribute, visit CPR's website at www.progressivereform.org.

455 Massachusetts Avenue, NW

\# 150-513

Washington, DC 20001

202-747-0698 (phone/fax)

$\mathrm{CPR}$ PROGRESSIVE REFORM

RETURN UNDELIVERABLES TO:

Center for Progressive Reform 455 Massachusetts Avenue, NW

\# 150-513

Washington, DC 20001 